\title{
RECENT TRENDS IN LAURENTIAN GREAT LAKES ICE COVER *
}

\author{
RAYMOND ASSEL ${ }^{1}$, KEVIN CRONK $^{2}$ and DAVID NORTON ${ }^{1}$ \\ ${ }^{1}$ Great Lakes Environmental Research Laboratory, National Oceanic and Atmospheric \\ Administration, 2205 Commonwealth Blvd, Ann Arbor, Michigan 48105-2945, U.S.A. \\ ${ }^{2}$ The University of Michigan, Cooperative Institute for Limnology and Ecosystems Research, 2200 \\ Bonisteel Boulevard, Ann Arbor, Michigan 48109-2099, U.S.A.
}

\begin{abstract}
A 39-winter (1963-2001) record of annual maximum ice concentration (AMIC), the maximum fraction of lake surface area covered by ice each year, is analyzed for each Great Lake. Lake Erie has the largest median AMIC (94\%) followed by Lakes Superior (80\%), Huron (63\%), Michigan (33\%), and Ontario (21\%). The frequency distribution of AMICs is negatively skewed for Lakes Superior and Erie and positively skewed for Lakes Michigan and Ontario. Temporal and spatial patterns of typical and extreme AMICs is presented within the context of long-term average air temperatures and lake bathymetry. The variation of spatially averaged ice concentration with discrete depth ranges are discussed for each lake for the upper and lower end of the typical range of AMIC values. In general, ice concentration decreases with increasing depth ranges for a given winter. A decrease in the gradient of ice concentration with depths was also observed with an increase in the AMIC from winter 1983 to winter 1984. A temporal trend in the AMICs supports the hypothesis of three ice cover regimes over the past 39 winters. Approximately $44 \%$ of the highest quartile (10 highest) AMICs for the Great Lakes occurred during the 6-winter period: 1977-1982 providing evidence of a higher ice cover regime during this period relative to the 14 winters before them (19631976) and the 19 winters after them (1983-2001). Winter 1998 established new low AMIC extremes, and the AMIC averaged over the 1998-2001 winters is the lowest for the period of record on four of the five Great Lakes. These recent trends taken together are noteworthy as they may be harbingers of a period of even lower AMICs in the 21st Century.
\end{abstract}

\section{Introduction}

Ice duration, the number of days between date of freeze-up and date of break-up, in lakes and rivers over the northern hemisphere has decreased over the 19th and 20th Centuries in response to global warming (Magnuson et al., 2000). These results are in agreement with regional trends of freeze-up dates (later) and break-updates (earlier) in the shore zone of the Laurentian Great Lakes of North America (Assel et al., 1995; Assel and Robertson, 1995). Our goal in this paper is to extend the Great Lakes analysis to the mid-lake areas of the Great Lakes by analyzing annual maximum ice concentration (AMIC), that is the greatest percentage of lake surface area covered by ice each winter. The specific objective of this study is to provide a benchmark of historical Great Lakes AMICs.

* The U.S. Government right to retain a non-exclusive royalty-free license in and to any copyright is acknowledged.

Climatic Change 57: 185-204, 2003.

(C) 2003 Kluwer Academic Publishers. Printed in the Netherlands. 
Ice cover affects mass and energy exchanges between a lake and the atmosphere. A lower ice cover regime in the Great Lakes during the 21st Century could have profound economic and aquatic system impacts. Potential economic impacts (Sousounis and Bisanz, 2000; Lofgren et al., 2001) include a longer shipping season, increased evaporation, lower lake levels, more dredging in navigation channels, lower ship cargo capacity, reduction of winter recreational and transportation activities (ice fishing, winter carnivals, transit over stable ice cover between islands and the mainland). Potential ecosystem impacts include reduced winter spawning habitat for some fish species and wetland habitat for land animals, a possible change in the Great Lakes fishery species composition (Magnuson et al., 1997), an increase in phosphorus concentrations (a major factor affecting lake eutrophication) (Nicholls 1998), and a change in winter zooplankton activity in areas where stable ice covers usually form (Vanderploeg et al., 1992).

This work builds on a preliminary analysis of a regional AMIC for the combined area of all five Great Lakes, (Assel et al., 2001). The time averaged AMIC over the winters 1998-2001 (32\%) is the lowest consecutive four-winter average over the period of record (from 1963 to 2001). Using Assel et al.'s (1985) regional AMIC model, which is based on air temperature, we found that the lowest fouryear running means prior to 1963 , for winters 1900 to 1962 , occurred in the early 1930s (35.6\% [1930-1933], 39.2\% [1929-1932]), and early-to-mid 1950s (39.8\% [1952-1955]). This provides a century time scale perspective of the contemporary regional four-winter average AMIC anomaly.

Typical and extreme AMICs for each Great Lake and differences among the five Great Lakes over the last four decades of the 20th Century are presented and discussed. Points of inquiry include: can variations in AMICs be explained by spatial variation in long-term average winter air temperatures, seasonal maximum Freezing Degree-days` (FDD), and lake bathymetric patterns; can large scale climatic forcing explain the extremes and trends in AMICs; and is there evidence of regional climatic warming over the period of record.

\section{Data and Analysis Methods}

\subsection{DATA SOURCES}

The AMIC data used in this study spans the winters from 1963 to 2001 and are calculated from historical ice charts. There are two types of historical ice charts: composite ice charts and synoptic ice charts. Composite charts have observations for the entire surface area of all five Great Lakes, but they may contain estimated ice conditions in areas not observed on the chart date. Ice conditions in these areas are

* A freezing degree day is the difference between the mean daily air temperature and $0{ }^{\circ} \mathrm{C}$. Values are positive if the mean is less than $0^{\circ} \mathrm{C}$ and negative if the mean is greater. A running sum of daily FDD starting in November was found to be useful index of ice formation on the Great Lakes. 
estimated based on an analysis of persistence, climatology, and weather conditions since the last observation. A synoptic ice chart usually only covers a portion of the Great Lakes, but observations are concurrent. Data for winters1973 through 1995 are calculated from composite ice charts digitized at the Great Lakes Environmental Research Laboratory (GLERL) (Norton et al., 2000). The original ice charts for that project were produced by the Canadian Ice Service (CIS) (for winters 1973 to 1995) and by the National Ice Center (NIC) (for winters 1989 to 1995). AMIC data for winters 1996 to 2001 are calculated from composite digital ice charts made available to the public by the NIC over the Internet (http://www.natice.noaa.gov/). AMIC data for winters 1963 through 1979 are abstracted from DeWitt et al. (1980). These AMIC values are calculated from synoptic ice charts produced by the CIS, GLERL, the National Oceanic and Atmospheric Administration's Lake Survey Center, the U.S. Army Corps of Engineers Lake Survey District, the U.S. Coast Guard, and the National Weather Service.

\subsection{METHOD USED TO CALCULATE AMIC}

The AMIC for a given winter and lake is defined as the ice chart having the largest lake-averaged ice concentration. The AMIC for each lake for a given winter is estimated from all available ice charts for that winter. The number of days between ice charts for a given winter season varied from 2 to 7 days and the date of the first ice chart each season ranged from December 6 to January 8, the date of last ice charts ranged from April 15 to May 31 (Table I). This frequency of observation and associated first and last dates of ice charts each season was considered to be adequate for the analysis of the AMIC. The methods used to calculate the AMIC were different for the synoptic and composite ice charts. For the synoptic ice charts which were only available as paper charts a visual inspection of all ice charts each winter was used to identify the one or two ice charts with the greatest ice concentration for each lake. Ice concentration in areas not observed on that synoptic ice chart were estimated based on a subjective analysis of all available information: ship reports, shore reports, and antecedent weather and ice conditions. Then a planimeter was used to measure the area of each discrete polygon on an ice chart. The lake-averaged ice concentration is the sum of the products of all polygon areas and associated ice concentrations (percent of area covered by ice) divided by the lake's total surface area. For the digitized composite ice charts ASCII files of $2.5 \mathrm{~km}$ grid cells of ice concentration were created for the surface area of the Great Lake. The ice concentration was averaged over all grid cells to calculate the lakeaveraged ice concentration for each lake on each composite ice chart for a given winter season.

\subsection{COMPARISON OF AMIC DATA}

Note that there is an overlap of seven winters in the synoptic and composite ice charts (winters 1973-1979). There is also an overlap of 7 years between NIC and 
Table I

Average number of days between ice charts for a season

\begin{tabular}{|c|c|c|c|c|c|c|c|c|}
\hline & \multicolumn{4}{|c|}{ Synoptic Ice Charts (1963-1979) } & \multicolumn{4}{|c|}{ Composite Ice Charts (1973-2001) } \\
\hline & Winter & $\begin{array}{l}\text { Fre- } \\
\text { quency }\end{array}$ & First $^{\mathrm{b}}$ & Last $^{b}$ & Winter & $\begin{array}{l}\text { Fre- } \\
\text { quency }\end{array}$ & First & Last \\
\hline Minimum & 1972 & 2 & Dec 28 & Apr 29 & 1992 & 2 & Dec 6 & May 11 \\
\hline Median & 1968 & 5 & Jan 8 & Apr 23 & 1979 & 6 & Dec 18 & May 14 \\
\hline Maximum & 1974 & 7 & Dec 31 & May 2 & 1981 & 7 & Dec 24 & Apr 15 \\
\hline
\end{tabular}

${ }^{a}$ Number of days between ice charts rounded to the nearest day.

$\mathrm{b}$ The date of first and last ice charts for the given winter.

CIS composite ice charts (winters 1989-1995). These overlap periods provide an opportunity to evaluate uncertainty in AMIC based on synoptic vs composite ice charts (winters 1973-1979) and based on different data sources (CIS vs NIC) for the composite ice charts (winters 1989-1995). Root Mean Square Differences (RMSD) (Table II) with two exceptions range from less than $1-11 \%$. The magnitude of this difference is less than or equal to the precision of reported ice concentration on original ice chart data observations, which are reported to the nearest $10 \%$ ice concentration. In the two cases that the RMSD was greater than $11 \%$, Lake Superior (16\% for GLERL-CIS comparison) and Lake Ontario (17\% GLERL-CIS comparison), one winter for each lake was responsible for the large RMSD: 1975 (Lake Superior), and 1973 (Lake Ontario) when the differences were 35\% and 43\% respectively. In both cases the CIS AMIC was much larger than the GLERL AMIC. Upon inspection of the original ice charts, the large difference was attributed to a transitory new thin ice cover reported on the CIS charts. This thin ice cover likely did not last more than a day or two as evidenced by its absence on the next ice chart in the series the following week. In both of these cases it is an open question as to which estimate of AMIC is more representative. For this reason it was arbitrarily decided to take an average when more than one AMIC was available for a given winter.

\section{Results and Discussion}

The spatial distribution of the AMICs for each Great Lake are discussed below within the context of lake bathymetric patterns (Figure 1a, Table III) and longterm average winter air temperatures (Figure 1b). The four highest and four lowest AMICs for each Great Lake are used to characterize the extremes. The 'typical' range of AMICs is defined here as the upper bound of the first quartile and the upper bound of the third quartile, that is the AMIC values at the 25th and 75th percentile of the cumulative frequency distribution (Table IV). Winter 1983 is used 


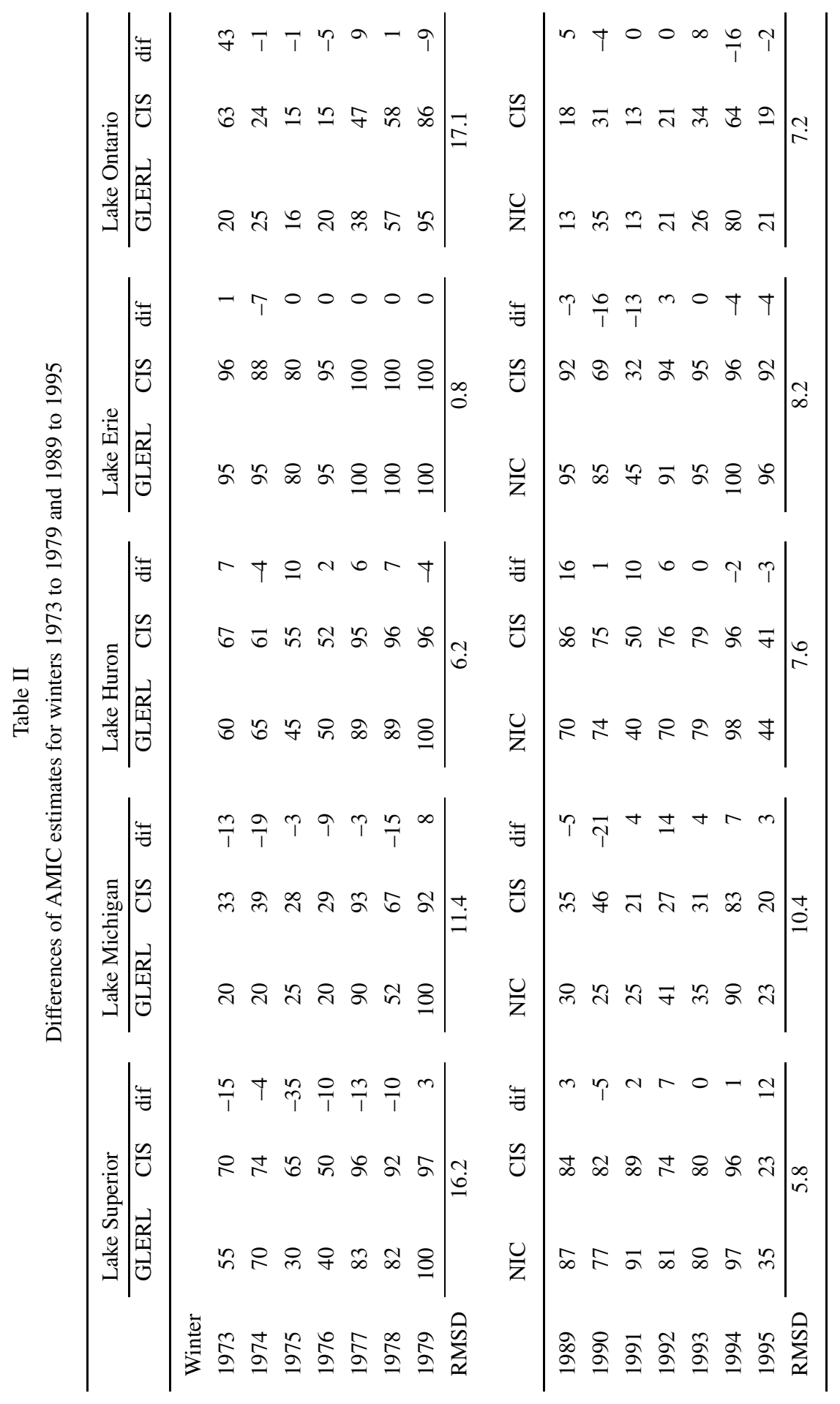


Table III

Great lakes features affecting AMIC

\begin{tabular}{|c|c|c|c|c|c|}
\hline & Superior & Michigan & Huron & Erie & Ontario \\
\hline Mean depth (m) ${ }^{\mathrm{a}}$ & 148 & 85 & 59 & 19 & 86 \\
\hline$<5 \mathrm{~m}^{\mathrm{b}}$ & 3.6 & 7.3 & 9.8 & 10.6 & 11.2 \\
\hline$>5 \mathrm{mbut} \leq 10 \mathrm{~m}^{\mathrm{b}}$ & $1.1 / 4.7$ & $3.7 / 11.1$ & $5.0 / 14.8$ & $10.6 / 21.2$ & $1.5 / 12.7$ \\
\hline$>10 \mathrm{~m}$ but $\leq 20 \mathrm{~m}^{\mathrm{b}}$ & $3.2 / 7.9$ & $8.4 / 19.5$ & $10.0 / 24.8$ & $41.5 / 62.7$ & $5.3 / 18.0$ \\
\hline$>20 \mathrm{mbut} \leq 40 \mathrm{~m}^{\mathrm{b}}$ & $5.4 / 13.3$ & $12.8 / 32.3$ & $17.3 / 42.1$ & $32.9 / 95.6$ & $12.5 / 30.5$ \\
\hline$>40 \mathrm{~m}$ but $\leq 60 \mathrm{~m}^{\mathrm{b}}$ & $5.0 / 18.3$ & $9.3 / 41.6$ & $17.8 / 59.9$ & $4.3 / 99.9$ & $8.5 / 39.0$ \\
\hline$>60 \mathrm{~m}$ but $\leq 100 \mathrm{~m}^{\mathrm{b}}$ & $10.7 / 29.0$ & $23.9 / 65.5$ & $23.3 / 83.2$ & $0.1 / 100$ & $18.9 / 57.8$ \\
\hline$>100 \mathrm{~m}$ but $\leq 200 \mathrm{~m}^{\mathrm{b}}$ & $47.9 / 76.9$ & $28.8 / 94.3$ & $16.7 / 99.9$ & $0.00 / 100$ & $39.8 / 97.6$ \\
\hline$>200 \mathrm{~m}^{\mathrm{b}}$ & $23.10 / 100$ & $5.7 / 100$ & $0.1 / 100$ & $0.00 / 100$ & $2.4 / 100$ \\
\hline Volume $\left(\mathrm{km}^{3}\right)^{\mathrm{c}}$ & 12,100 & 4,920 & 3,540 & 484 & 1,640 \\
\hline Maximum FDD $\left({ }^{\circ} \mathrm{C}\right){ }^{\mathrm{d}}$ & 1280 & 498 & 696 & 270 & 353 \\
\hline Maximum FDD $1979^{\mathrm{e}}$ & 1250 & 816 & 903 & 400 & 516 \\
\hline Maximum FDD $1998^{\mathrm{e}}$ & 491 & 128 & 323 & 28 & 62 \\
\hline
\end{tabular}

\footnotetext{
${ }^{a}$ Mean depth is lake volume divided by the surface area.

$\mathrm{b}$ Percent of lake within indicated depth range / cumulative percentage.

${ }^{c}$ Lake volume is an index of lake heat storage capacity. ${ }^{d}$ Long term average FDD (1963-1998) modified from Rodionov and Assel (2001). ${ }^{\mathrm{e}}$ Stations for each Lake are: L. Superior (Sault Ste. Marie, MI), L. Michigan (Milwaukee, WI), L. Huron (Alpena, MI), Lake Erie (Cleveland, OH.), and L. Ontario (Buffalo, NY).
}

to portray the spatial patterns of ice relative to lake bathymetry near the upper boundary of the first quartile, and winter 1984 is used to illustrate lake bathymetry related spatial patterns of ice concentration near the upper boundary of the third quartile (Figure 2). The AMICs for Lakes Superior and Erie are skewed to the right of the mean, and the AMICs for Lakes Michigan and Ontario are skewed to the left (Figure 3). For this reason the median and not the mean was chosen as a reference in the portrayal of temporal patterns of AMICs for each Great Lake (Figure 4).

\subsection{LAKE SUPERIOR}

This lake is the farthest north and west of the Great Lakes (centered approximately $47.5^{\circ} \mathrm{N}, 88^{\circ} \mathrm{W}$ ). It has the greatest mean depth, largest heat storage capacity, and lowest air temperatures (Figure 1b). Winter air temperatures are low enough most winters to produce an extensive ice cover (Figure 4a). The typical AMIC ranges from $46 \%$ to $89 \%$. During winters 1983 and 1984 the AMIC was $20 \%$ and $88 \%$ respectively. The spatially averaged ice concentration in the waters up to $10 \mathrm{~m}$ deep was nearly the same for both winters, while differences between spatial averages of ice concentration for depths greater than $10 \mathrm{~m}$ increases with depth (Figure 2a). For 


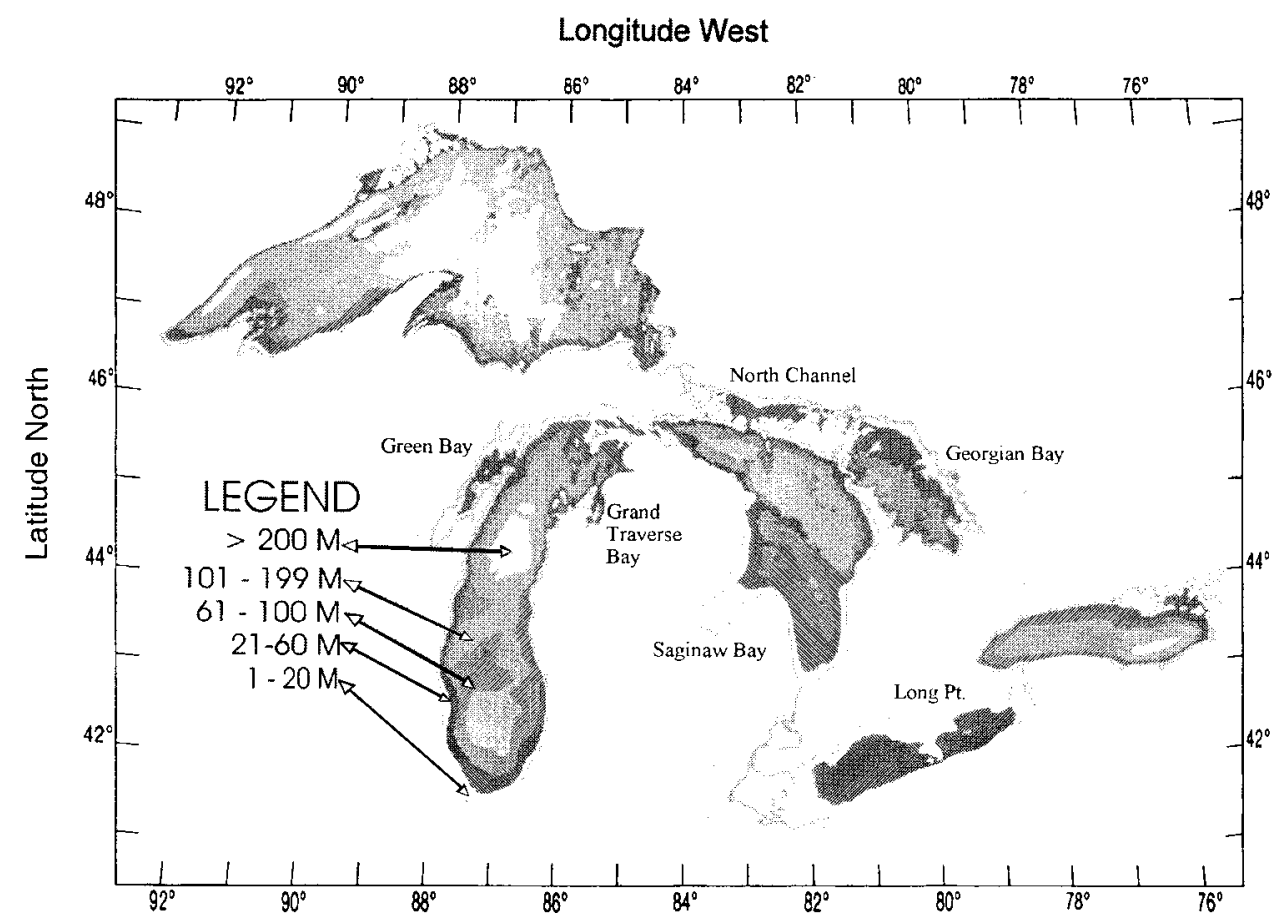

Figure 1a. Lake bathymetry, depth ranges of $\leq 20 \mathrm{~m}$ and $>200 \mathrm{~m}$ are white, while the shallowest depths $>20 \mathrm{~m}$ have the darkest shading.

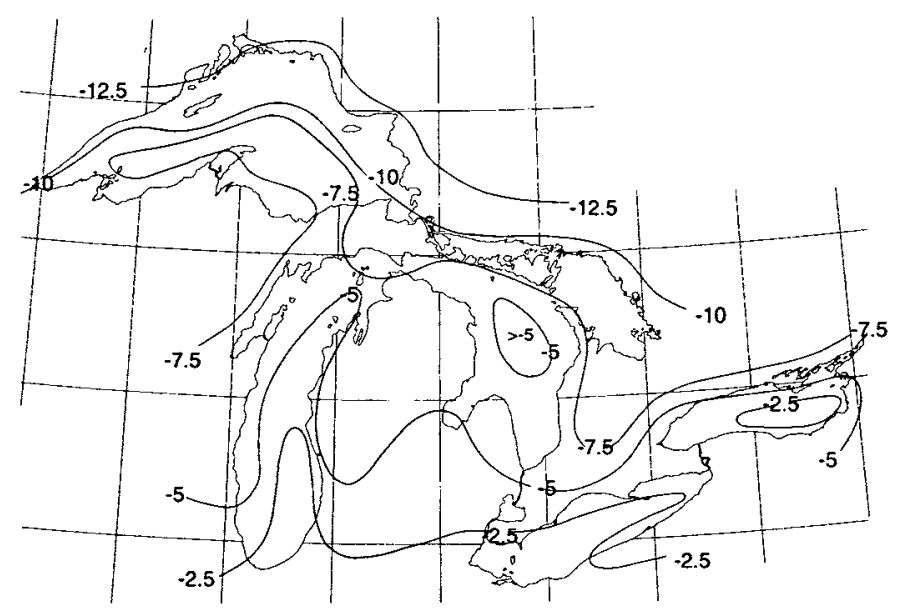

Figure 1b. Mean (1951-1980) February air temperature $\left({ }^{\circ} \mathrm{C}\right)$ abstracted from Environment Canada (1986). 

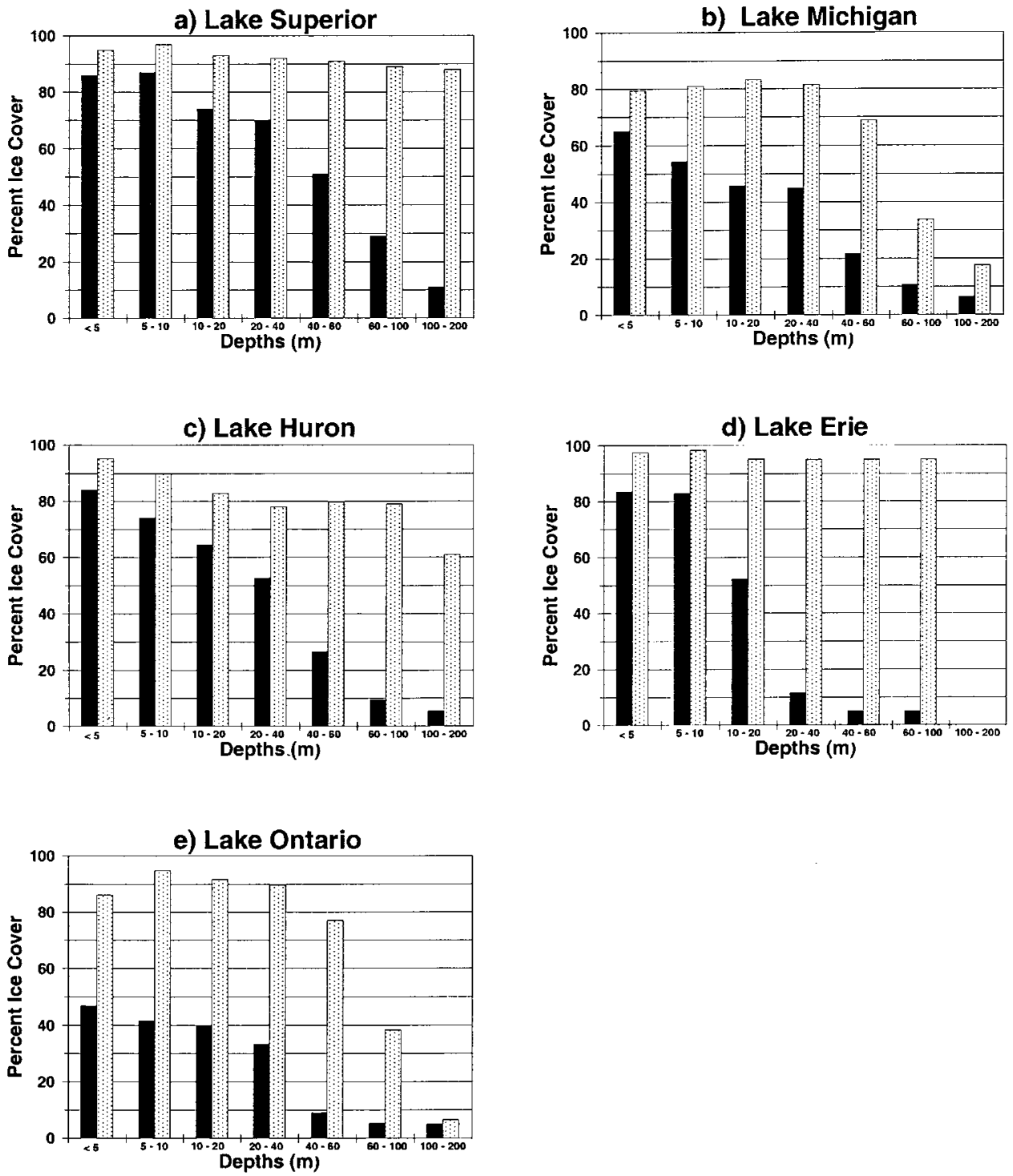

Figure 2. Spatial averaged ice concentration of AMIC for discrete depth ranges for winters 1984 (white bars) and 1983 (black bars) for Lakes: (a) Superior, (b) Michigan, (c) Huron, (d) Erie, and (e) L. Ontario.

example, for lake depths between $60 \mathrm{~m}$ and $100 \mathrm{~m}$, ice concentration in winter 1983 was about $60 \%$ less than it was in 1984. Approximately $71 \%$ of Lake Superior's waters are over $100 \mathrm{~m}$ deep (Table III), and this is where the largest differences in ice concentration (Figure 2a) between winters 1983 and 1984 occurred. The 100 $\mathrm{m}$ contour, running north of the shoal areas along the southern shores and south of the three large bays along the north-central shore, demarcates an approximate 
a) Superior

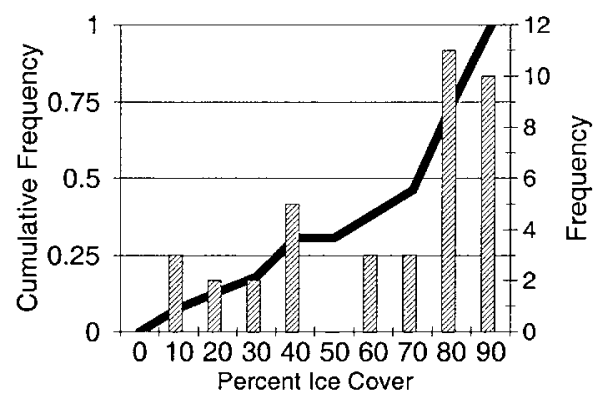

c) Huron

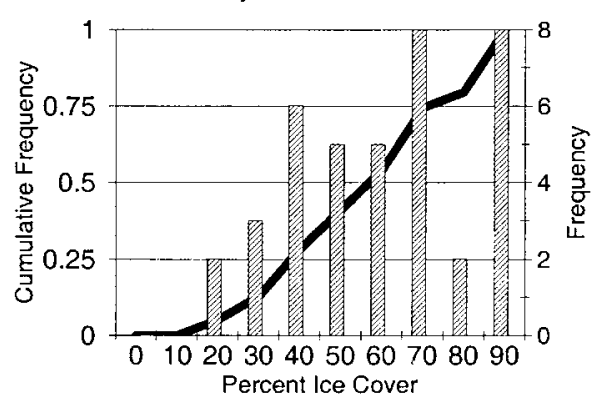

e) Ontario

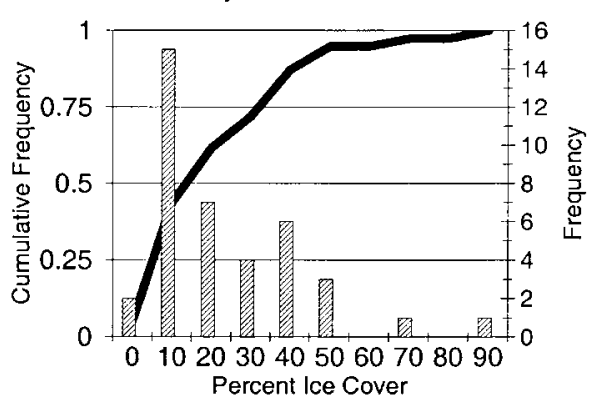

b) Michigan

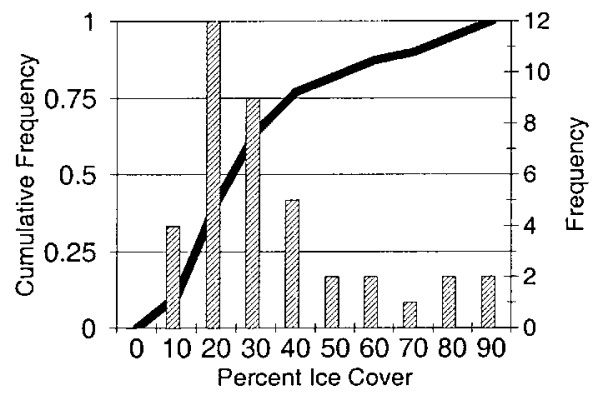

d) Erie

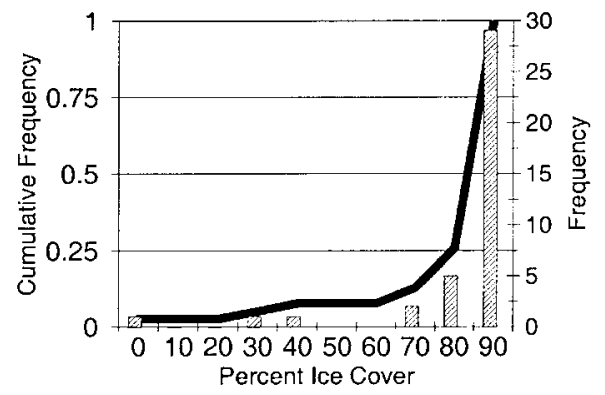

Figure 3. Histogram of AMIC for Lakes: (a) Superior, (b) Michigan, (c) Huron, (d) Erie, and (e) Ontario. Solid line is cumulative frequency distribution (cfd) and bars are frequency of occurrence for a given ice cover range. Typical AMIC values are defined as those that range between the 25th and 75 th percentile of the cfd.

boundary between the shallower (near shore) and deeper (mid-lake) waters of Lake Superior. The lowest ice concentration occurs in the depths greater than $200 \mathrm{~m}$ (Figure 1a). Under the climate of the last four decades of the 20th Century the mid-lake areas developed extensive ice covers over more than half the winters (Figure 3a); the median AMIC is $80 \%$, and the average is $68 \%$ (Table IV). When air temperatures are extremely mild the mid-lake and many deeper near-shore areas 

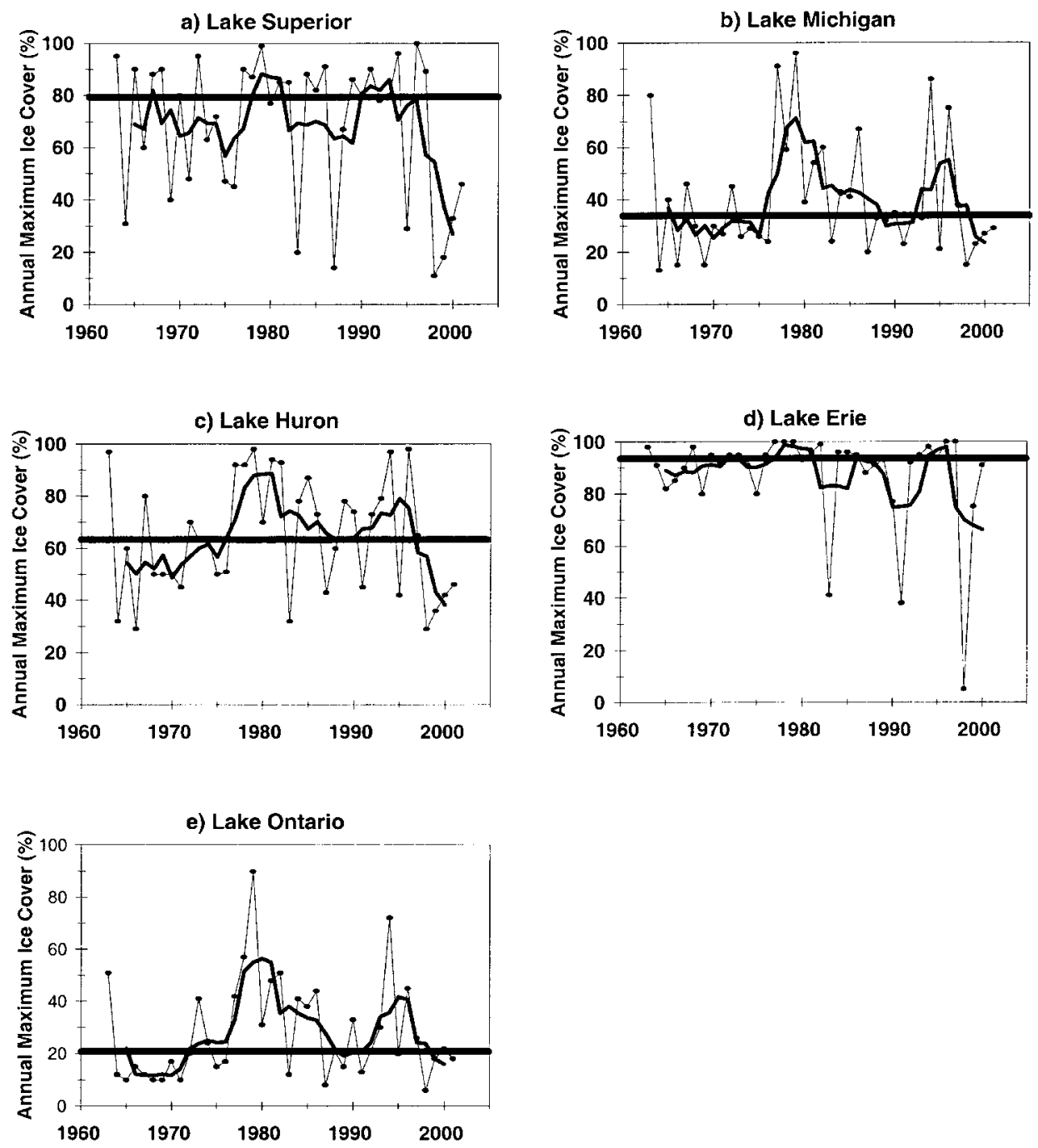

Figure 4. The AMICs for Lakes: (a) Superior, (b) Michigan, (c) Huron, (d) Erie, and (e) Ontario. Heavy sold horizontal line is the median. Light solid line is AMIC, medium heavy line is 4-winter running average of AMIC plotted on 3rd winter. The four winter running average plot facilitates comparison of previous consecutive four winter periods with the 1998 to 2001 winter average that was the lowest on record for all lakes except Lake Ontario. Lakes Superior and Erie's median AMICs are high ( $80 \%$ and $94 \%$, respectively) and the opposite is true of the other lakes. Thus, only during extremely high AMIC values will Superior and Erie's 4-winter running average AMIC exceed the median, this is not true for Lakes Michigan, Huron, and Ontario. 
remain open water or have low ice concentrations. The four highest and four lowest AMICs are $95 \%$ or more and $20 \%$ or less, respectively. Highest AMICs occurred in winters 1963, 1994, 1979, and 1996; lowest AMICs occurred in winters 1998, 1987, 1999, and 1983. The average AMIC for the four winters 1998, 1999, 2000, and 2001 is the lowest four-year average on record (27\%).

\subsection{LAKE MICHIGAN}

Lake Michigan, with a large air temperature gradient in winter along its longitudinal axis $\left(42^{\circ} \mathrm{N}\right.$ to $46^{\circ} \mathrm{N}$, Figure $\left.1 \mathrm{~b}\right)$, usually has the main body of its ice cover located in the shoal areas of the northern end of the lake and in Green Bay (Figure 1a). Water depths in these areas and along the perimeter of the rest of the lake are $60 \mathrm{~m}$ or less. High AMICs (over $40 \%$ ) occur only when extensive ice forms in water depths over $60 \mathrm{~m}$. Water depths greater than $60 \mathrm{~m}$ occur over approximately $52 \%$ of Lake Michigan and occupy the mid-lake areas. Typical AMICs range from $24 \%$ to $45 \%$. The AMIC in 1983 and 1984 were $24 \%$ and $43 \%$ respectively. In 1984 , ice concentration for waters with depths less than $40 \mathrm{~m}$ averaged about $80 \%$ and lined the entire perimeter of the lake (Figure $2 b$ ). The slight increase in ice concentration in the $10-20 \mathrm{~m}$ range relative to the 5-10 $\mathrm{m}$ and less than $5 \mathrm{~m}$ ranges is due to lower ice concentrations along the western lake shore at these depths. Ice concentration differences of 15-50\% between 1983 and 1984 are due to a lack of ice in the southern half of the lake in 1983 and due to lower ice concentrations along the northern shores.

The long term average AMIC is near $40 \%$, but the ice cover is less than that for most winters (Figure 4b, Table IV). The extreme low AMIC's range from 13\% to $15 \%$ (winters: $1964,1998,1966,1969$; corresponding to about the $15 \mathrm{~m}$ depth contour). The extreme high AMICs range from 80\% to 96\% (winters: 1963, 1994, 1977, 1979). Assel and Quinn (1979) show that the higher AMIC values only occur when much-below-average air temperatures persist over the southern half of the lake. Low AMIC values occur when the Tropical Northern Hemispheric index is less than or equal to 0.2 (Rodionov et al., 2001). The most recent 4-year average AMIC (23\% for 1998 through 2001) sets a new record low for the 39-winter base period. Grand Traverse Bay, located on the northeast shore of Lake Michigan, had not frozen over in the past five winters, an event not equaled in its 150 years of ice records there, lending credence to the supposition of a recent trend for lower AMICs.

\subsection{LAKE HURON}

The bulk of this lake is in a latitude band $\left(44^{\circ} \mathrm{N}\right.$ to $\left.46^{\circ} \mathrm{N}\right)$ similar to that of the north half of Lake Michigan, and, in general, winter air temperatures are lower than they are for southern Lake Michigan (Figure 1b). The mean water depth (58 $\mathrm{m}$ ) is the second lowest in the Great Lakes. (Table III). Typical AMIC values range from 45\% to 79\% (Figure 4c, Table IV). In 1983 and 1984 the AMIC was 32\% 
Table IV

Summary statistics for annual maximum ice cover

\begin{tabular}{lrrlllll}
\hline Lake & Maximum & Minimum & $\begin{array}{l}\text { First } \\
\text { quartile }\end{array}$ & $\begin{array}{l}\text { Third } \\
\text { quartile }\end{array}$ & Median & Average & Std. dev. \\
\hline Superior & 100 & 11 & 46 & 89 & 80 & 68.3 & 27.1 \\
Michigan & 96 & 13 & 24 & 45 & 33 & 39.6 & 21.9 \\
Huron & 98 & 29 & 45 & 79 & 63 & 64.3 & 21.9 \\
Erie & 100 & 5 & 88 & 96 & 94 & 87.5 & 19.1 \\
Ontario & 90 & 6 & 13 & 41 & 21 & 27.8 & 19.0 \\
\hline
\end{tabular}

and $78 \%$ respectively. Differences in spatial average ice concentrations for depths greater than $40 \mathrm{~m}$ are over $50 \%$ (Figure 2c). Waters with depths less than or equal to $40 \mathrm{~m}$ have ice concentration differences of approximately $10 \%-25 \%$. About $42 \%$ of Lake Huron's waters are less than or equal to $40 \mathrm{~m}$ deep and are located in the shallows of Georgian Bay, North Channel in the north, Saginaw Bay in the south, and in a narrow band along the entire perimeter of the lake (Figure 1a). These shallow areas usually have extensive ice cover every winter. Typical AMICs occur when ice also forms in water depths ranging from 41 to $100 \mathrm{~m}$. These water depths constitute about $41 \%$ of the lake's surface (Table III) and are distributed as shown in Figure 1a. The greatest AMICs occur only when ice forms in lake waters over $100 \mathrm{~m}$ deep.

The long-term average AMIC (64\%) is similar to Lake Superior's, but unlike Lake Superior its median and average AMIC are virtually the same (not a skewed distribution). The four lowest AMICs range from 29\% to 32\% (winters: 1998, 1966, 1983, 1964); the four highest AMICs range from 97\% to $98 \%$ (winters: 1994, 1963, 1996, 1979). The relatively high value of the four lowest AMICs, which is higher than Lake Erie's lower extreme (Table IV), is due to the extensive shallow water areas in the northern end of the lake where air temperatures are much lower than in southern Lake Huron (Figure 1b). A contributing factor to Lake Huron's greater minimum AMIC, relative to Lake Erie's, is lower winter air temperatures in southern Lake Huron where water depths in Saginaw Bay and the southern perimeter of Lake Huron are similar to water depths over the shallow western basin of Lake Erie (Table III, Figure 1). The most recent 4-year average AMIC (38\%) is the lowest on record.

\subsection{LAKE ERIE}

Lake Erie's AMIC is strongly skewed to higher values (Figure 3d), its median is $94 \%$, its average $87 \%$. The high AMICs are due to the prevalence of shallow waters, approximately $21 \%$ of its depths are less than or equal to $10 \mathrm{~m}$ deep. A 
previous study (Assel, 1991), indicates that under the current climate only 27 FDDs are needed before shallow waters (depths less than or equal to $10 \mathrm{~m}$ ) of Lake Erie cool to the point that further cooling results in ice formation. In winter 1998, the maximum FDD accumulation was 28, and the AMIC was only 5\%. Long-term seasonal maximum FDD accumulations average 270 (Table III). Typical Lake Erie AMICs range from $88 \%$ to $96 \%$ (Table IV). Ice first forms in the shallow western basin (bounded by the island area to the western end of the lake, average depth approximately $10 \mathrm{~m}$ ) and along the perimeter of the lake. Next, ice forms in the mid-lake basin (eastward of the islands to Long Point with an average depth of about $19 \mathrm{~m}$ ). Ice forms last in the deepest area off of Long Point (between Long Pt. and the east end of the lake, with an average depth of about $27 \mathrm{~m}$ ). In winter 1983, the AMIC was only $41 \%$ while in winter 1984 it was $96 \%$. The major differences in ice cover between 1983 and 1984 occurred in water with depths over $10 \mathrm{~m}$ deep (Figure 2d). The 1983 ice was present in the west lake basin with a relatively narrow band of ice running along the entire length of the northern shoreline; the main body of the east and central basins were open water. Virtually 100\% of the lake was ice covered for winters 1996, 1979, 1978, 1977, and 1997. The lowest AMIC's range from 5\% to 75\% in winters 1998, 1991, 1983, and 1999. The increased frequency of low AMIC's in the decade of the 1990s is quite evident (Figure 4d). The remarkably low AMICs (5\%, 75\%) in 1998 and 1999 respectively contributed to the lowest four-winter (1998-2001) average (66\%) on record.

\subsection{LAKE ONTARIO}

Lake Ontario (between $43^{\circ} \mathrm{N}$ to $44^{\circ} \mathrm{N}$ ) is the farthest east and second farthest south of the Great Lakes. Cold air outbreaks from the northwest and west are moderated by the waters of Lakes Superior, Michigan, and Huron. Its mean depth (86 m) is similar to Lake Michigan's. The gradient of depth is large along the southern shore, more moderate along the northern shore (Figure 1a), and mid-lake waters are greater than $100 \mathrm{~m}$ deep. Given this mean depth, depth configuration, and relatively mild winter air temperature regime (Figure 1b), the potential for extensive ice formation on Lake Ontario is small. Not surprisingly, its AMIC is the lowest of the Great Lakes (Figure 4e) with a median of $21 \%$ and a average of only $28 \%$. Typical AMICs range from $13 \%$ to $41 \%$. In winter 1983, the AMIC was $12 \%$ while in winter 1984 it was $41 \%$. Near the end of the first week of February 1983, the time of the AMIC, the bulk of the ice cover was located in the shallow bays and the lake area along the northeast shores, in water with depths less or equal to $40 \mathrm{~m}$. This area of the lake usually has the lowest average February air temperatures (Figure 1b). In winter 1984, the AMIC occurred several days past mid-January. At that time, extensive ice cover lined most of the shore zone out to areas with depths of $60 \mathrm{~m}$ (Figure 2e); mid-lake areas with depths over $100 \mathrm{~m}$ were still primarily ice free and waters with depths between $60 \mathrm{~m}$ and $100 \mathrm{~m}$ had a little less than $40 \%$ ice cover. Ice cover in waters with depths over $40 \mathrm{~m}$ lasted less than a week 
in 1984. Waters with depths of less than $5 \mathrm{~m}$ (Table III) make up about $11 \%$ of Lake Ontario's surface area. This depth range and surface area combination (low heat storage, small percent of lake surface area) is in agreement with the observed lowest AMICs which ranged from 6\% to $10 \%$ (1998, 1987, 1965, 1968, 1969, 1971) and may approach the lower limit of AMIC on Lake Ontario for the current climate. At the other end of the spectrum, the four highest AMICs ranged from $51 \%$ to $90 \%$ (winters 1963, 1982, 1978, 1994, 1979). The AMIC averaged over the most recent four winters (1998-2001) is 16\%. The four-winter average AMIC was lowest in the mid 1960s to 1971 (Figure 4e).

\section{Temporal Patterns in the AMIC}

Periods of increase, decrease, and little change in AMICs are coincident for all Great Lakes most winters (see four-year running average on Figure 4). The correlation coefficient of AMIC time series for any two of the Great Lakes is a measure of the temporal coherence of their AMICs. The correlation coefficients for the ten possible combinations of lake pairs has a median of 0.62 , a maximum of 0.85 , and a minimum 0.42 . This coherence is likely due to the effects of large scale atmospheric forcing on the regional Great Lakes climate. Previous studies (Rogers, 1976; Assel, 1990) identified a biannual periodicity in the annual ice cycle that corresponds to the quasi-biennial oscillation phenomenon in the atmosphere (Landsberg, 1962; Angell and Korshover, 1968). More recently Assel (1998) found evidence that statistically significant lower AMICs (of the combined area of the Great Lakes) occurs in the winters following the start of a strong warm El Niño event. Assel and Rodionov (1998) found that $46 \%$ of the lowest quartile AMICs (of individual Great Lakes between winters 1963 and 1990) occurred the winter following the start of a warm El Niño. They also found that $66 \%$ of the highest quartile AMICs (7 highest for the base period 1963-1990) occurred during the six winters from 1977 to 1982 and that the mean AMIC at individual Great Lakes was significantly higher during these winters (1977-1982) than the winters before that period (from 1963 to 1976) and winters after that period (from 1983 to 1990). This suggests the hypothesis: a lower ice cover regime occurred from 1963 to 1976, a higher ice cover regime from 1977 to 1982, and a second lower ice cover regime from 1983 to 1990 relative to the average over the period 1963-1990. Our results are in agreement with this theory for the winters from 1963 to 2001: a disproportionately high percentage (44\%) of the highest quartile (10 highest) AMICs for the Great Lakes occurred during the six winters from 1977 to 1982 and none of the lowest quartile (10 lowest) AMICs occurred during these winters; $40 \%$ of the 10 lowest AMICs occurred in the winters 1964-1976 and 60\% occurred during the winters 1983-2001. A nonparametric sign test for the median (Ferguson, 1976, p. 384) of the AMICs over the 1977-1982 winters relative to the other winters of the 39-winter base period shows a significant difference in medians for Lakes Michigan, Huron, 
and Ontario, $\alpha=5 \%$ level, for Superior, $\alpha=17 \%$ level, and Erie, $\alpha=14 \%$ level, where $\alpha$ is the probability of a Type I error (Ferguson, 1976, p. 161-162), that is rejecting the null hypothesis when it is false. The lower sensitivity for Superior and Erie is due to their high medians ( $80 \%$ and $94 \%$ respectively). There was no significant differences ( $\beta=5 \%$ level) in the median AMIC before and after the winters of the high ice cover regime (1977-1982), where $\beta$ is the probability of a Type II error (Ferguson, 1976, p. 161-162), that is accepting the null hypothesis when it is false.

Departures from the median AMIC for all lakes were negative for the most part in the 1960s to the early to mid 1970s (Figure 4). A dramatic increase in AMICs started in the mid-to-late 1970s and ended in the early 1980s. Lakes Michigan and Ontario set record high AMICs in winters 1979, which still stand today. Winter 1979 is arguably the single most severe ice season in the 39-winter period of record. The AMICs on all the Great Lakes were above their median for all or most of these winters (1977-1982). Thus, the Great Lakes AMIC had abruptly shifted to a higher ice cover regime starting in 1977. That winter also corresponds with the start of an interdecadal change in the northern hemispheric atmospheric circulation regime (Trenberth, 1990). El Niño and La Niña events were conspicuous by their absence during winters 1977-1982. The (winter) upper air circulation pattern shifted to included a stronger Aleutian Low displaced farther eastward and a intensification of the ridge over the Rocky Mountains along the west coast of North America and trough over the southeast United States. Rodionov et al. (2001) found that upper air circulation patterns associated with above average AMIC also include an intensification of the upper air $(700 \mathrm{mb})^{\star}$ Hudson Bay Low, which results in cold Arctic air advection toward the Great Lakes.

A sharp decline in AMIC occurred in winter 1983 in response to the record El Niño event that year (Assel et al., 1985). That winter set new record low AMICs for Lakes Superior and Erie; the other three Great Lakes were near record lows set in the 1960s. A more moderate downward trend in AMICs continued the rest of 1980s and into the early 1990s, ending in 1993. El Niño events occurred in 1987, 1991, 1992, and 1993, and La Niña events occurred in 1984 and 1988. The 1987 AMIC set a new low for Lake Superior (14\%), and the 1991 El Niño coincided with a new record low AMIC for Lake Erie (38\%). The AMICs for the other Great Lakes were also low in winter 1987 and 1991, with the exception of Lake Superior in 1991 (90\%). There is sometimes a disconnect between Lake Superior's AMIC and the rest of the Great Lakes because of its more northerly and westerly displacement relative to the rest of the Great Lakes (Figure 1). Rodionov and Assel (2000) have shown that larger negative departures of average winter air temperatures occur in the vicinity of Lake Superior compared to the other Great Lakes when the upper air $(700 \mathrm{mb})$ circulation pattern over North America is characterized by a sup-

^ A millibar (mb) is a measure of atmospheric pressure, $700 \mathrm{mb}$ refers to surface of equal pressure in the upper atmosphere approximately 275 to $315 \mathrm{~m}$ above the earth's surface. 
pressed ridge over the Rocky Mountains in combination with an intensification of the Hudson Bay Low.

A period of large interannual change in AMIC's occurred in the mid 1990s due to two severe winters $(1994,1996)$ with a mild winter $(1995)$ between them. There was an El Niño in winter 1995 but not in winters 1994 and 1996. Winter 1994 was perhaps the most severe winter in over a decade (Assel et al; 1996), and winter 1996 was comparable. The AMICs for both these winters were similar to winter 1979. Thus, severe winters can occur in a period of otherwise generally mild winters. Winter 1995 was mildest on Lake Superior, where the AMIC was only $29 \%$. The AMIC was also well below the median that winter on Lakes Michigan and Huron, with values of $21 \%$ and $42 \%$ respectively. Lake Erie's 1995 AMIC was at its median value of 94\%. Lake Ontario's 1995 AMIC was a little below its median and did not last more than a few days.

The last five winters (1997-2001) include a record El Niño winter (1998) followed by two La Niña winters (1999-2000). The extremely mild winter of 1998 established new record low AMICs on Lakes Superior, Huron, Erie, and Ontario, and was the second lowest AMIC on Lake Huron (Assel et al., 2000). Lakes Erie and Ontario were virtually ice free in winter 1998 (AMICs of 5\% and 6\%, respectively). Ice on the other lakes was limited to the shallower areas of large bays and other shallow shore regions. Winter 1998 was followed by three mild winters. The AMICs for these winters is similar to some of the projections of ice covers under greenhouse warming scenarios (Assel, 1991; Lofgren et al., 2001).

\section{Summary and Conclusions}

The spatial pattern of water depths on each lake and regional differences in winter air temperatures over the Great Lakes basin contributed to the observed differences in AMIC among the five Laurentian Great Lakes. Heat storage capacity is proportional to water depth, and air and water-temperature difference is an index of potential for heat loss at the lake's surface. In winter the water temperature is near $0^{\circ} \mathrm{C}$, so variations in air-water temperature differences are due in large part to variations in air temperatures. Air temperatures in the form of accumulated FDDs has been shown to be correlated with ice cover (Assel, 1991; Rogers, 1976; Richards, 1964). The seasonal maximum FDDs for the winters with the greatest and least ice covers (1979 and 1998) are given in Table III and show that there has been a large variation in ice forming potential over the last four decades of the 20th Century. The greatest climatic potential for ice formation in terms of FDDs occurs on Lake Superior where the long-term average annual maximum FDDs is 1280, and least on Lake Erie where it is 270 (Table III). However, because over $61 \%$ of Lake Erie's depths are less than or equal to $20 \mathrm{~m}$ it forms the greatest AMIC despite its lower 'climatic potential' for ice formation. Depths less than or equal to $20 \mathrm{~m}$ make up approximately $8 \%, 19 \%, 25 \%$, and $18 \%$ of the waters on Lakes Superior, 
Michigan, Huron, and Ontario respectively (Table III), so it is apparent that in this respect (water depth), Lake Erie is in a class by itself. Lake Superior has the next highest AMIC due to its large FDD accumulations most winters. Lake Huron has the third largest AMICs because of a combination of lower air temperatures and larger percentage of its waters with depths less then or equal to $60 \mathrm{~m}$ relative to Lakes Michigan and Ontario (approximately $60 \%$ for Huron, $41 \%$ for Michigan, and 39\% for Ontario). Lake Michigan has larger AMICs than Lake Ontario because of the lower air temperatures and large shallow areas in the northern third of that lake (Michigan).

The inter-annual differences in AMIC is affected by the inter-annual variation in winter air temperatures (Rogers, 1976) and is reflected by the gradient of ice concentrations with lake depths. Higher ice concentrations occur over deeper waters in winters with lower air temperatures (e.g., 1984, Figure 5a) than in winters with higher air temperatures (e.g., 1983, Figure 5b). In general the gradient of ice concentration with depth approaches zero as the AMIC approaches its upper bound $(100 \%)$. Under the current climate, this occurs most frequently on Lakes Erie and Superior because of their high median AMIC.

Large scale atmospheric circulation patterns are related to both AMICs (Assel and Rodionov, 1998; Rodionov et al., 2001) and to mean winter air temperatures (Rodionov and Assel, 2000). In general, above average AMIC is associated with meridional (north-south) circulation over North America characterized by an amplification of the $700 \mathrm{mb}$ ridge over the west coast, a deepening of the trough over the southeastern United States, and deepening of the low pressure center over Hudson Bay, resulting in cold air advection from northern Canada and the Arctic. Below average AMIC is in general associated with zonal (west-east) circulation characterized by weakening of the $700 \mathrm{mb}$ ridge over the west coast, weakening of the trough over the southeastern United States, and weakening of the Hudson Bay low pressure center, resulting in advection of milder air of Pacific Ocean origin. Perhaps the single most important large scale forcing associated with some of the below-average AMICs is El Niño events. During the one extended period without El Niño/La Niña events (1977-1982) the AMIC regime was greater than either the period prior to it (1963-1976) or the period that followed it (1983-2001).

Under the climate of the last four decades, extremes in AMIC have ranged from ice only along the perimeter of the Great Lakes to ice coverage of over 90\%. The winters when two or more of the Great Lakes experienced one of their four highest AMICs include: 1979 (5), 1994 (4), 1996 (3), 1963 (3), 1978 (2), and 1977 (2). The winters when two or more of the Great Lakes experienced one of their four lowest AMICs include: 1998 (5), 1983 (3), 1999 (2), 1987 (2), 1969 (2), 1966 (2), and 1964 (2). The contemporary four-winter average AMIC (1998-2001) was the lowest on record, and Lake Erie was virtually ice free in winter 1998. While these trends are not of sufficient duration to conclude a change in ice cover regime has occurred, they are noteworthy. If the recent trend for mild winters continues over the next decade or two the ice cover of the late 1990s will indeed be recognized as 
a) 1984

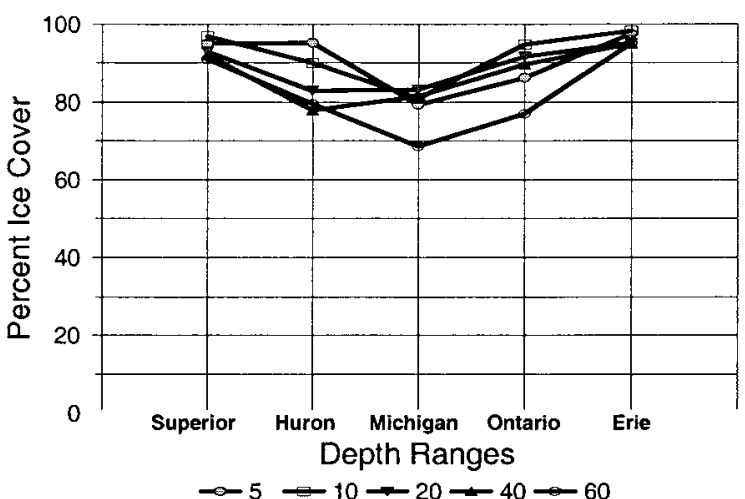

b) 1983

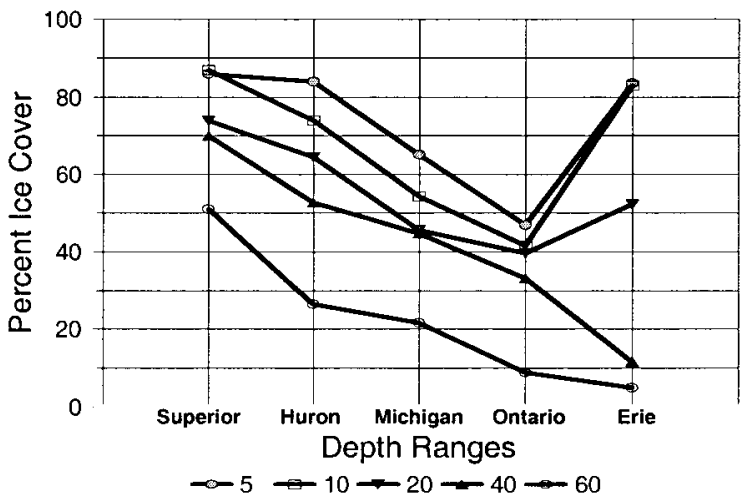

Figure 5. Spatial averaged ice concentration of AMIC for discrete depth ranges for the 1984 (a) and 1983 (b) winter seasons.

the harbinger of a new and yet lower ice cover regime. The information on AMICs given here will be useful for placing ice covers of the 21st Century in a historical perspective and providing data for detecting a possible change in the ice cover regime.

\section{Acknowledgements}

This is GLERL Contribution Number 1245. This work was funded in part by a proposal submitted to the Cooperative Institute for Limnology and Ecosystems Research (CILER), University of Michigan, under the Scientific Enhancement Program for year 2000. Dr. D. Beletsky (of CILER) provided computer programing 
assistance in the development of the Great Lakes bathymetry graph. Dr. B. Lofgren (of GLERL) and the three anonymous reviewers provided valuable comments for this paper.

\section{References}

Angell, J. D. and Korshover, J: 1968, 'Additional Evidence for Quasi-Biennial Variations in Tropospheric Parameters,' Mon. Wea. Rev. 96, 778-784.

Assel, R. A.: 1990, 'An Ice-Cover Climatology for Lake Erie and Lake Superior for the Winter Seasons $1897-98$ to $1982-83$ ', Int. J. Clim. 10 731-748.

Assel, R. A.: 1991, 'Implications of $\mathrm{CO}_{2}$ Global Warming on Great Lakes Ice Cover', Clim. Change 18, 377-395.

Assel, R. A.: 1998, 'The 1997 ENSO Event and Implications for North American Laurentian Great Lakes Winter Severity and Ice Cover', Geophys. Res. Lett. 25 (5).

Assel, R. A., Herche, L., and Cronk, K.: 2001, Contemporary and Possible Future Great Lakes Ice Cover, Presentation at the XXVIII Congress of the Society of International Limnology, Monash University, Melbourn, Australia, Feb. 6, 2001.

Assel, R. A., Janowiak, J., Boyce, D., Oconnors, C., Norton, D., and Quinn, F.: 2000, 'Laurentian Great Lakes Ice and Weather Conditions for the 1998 El Niño Winter', Bull. Amer. Meteorol. Soc. 81 (4), 703-717.

Assel, R. A., Janowiak, J., Boyce, D., and Young, S.: 1996, 'Comparison of 1994 Great Lakes Winter Weather and Ice Conditions with Previous Years', Bull. Amer. Meteorol. Soc. 77 (1), 71-88.

Assel, R. A. and Quinn, F. H.: 1979, 'A Historical Perspective of the 1976-77 Lake Michigan Ice Cover', Mon. Wea. Rev. 107, 336-341.

Assel, R. A. and Robertson, D. M.: 1995, 'Changes in Winter Air Temperatures near Lake Michigan during 1851-1993, as Determined from Regional Lake-Ice Records', Limnol. Oceanogr. 40 (1), $165-176$.

Assel, R. A., Robertson, D. M., Hoff, M., and Selgery, J.: 1995, 'Climatic Change Implications of Long-Term (1823-1994) Ice Records for the Laurentian Great Lakes', Ann. Glaciol. 21, 383386.

Assel, R. A. and Rodionov, S.: 1998, 'Atmospheric Teleconnections for Annual Maximal Ice Cover on the Laurentian Great Lakes', Int. J. Clim. 18, 425-442.

Assel, R. A., Snider, C. R., and Lawrence, R.: 1985, 'Comparison of 1983 Great Lakes Winter Weather and Ice Conditions with Previous Years', Mon. Wea. Rev. 113, 291-303.

DeWitt, B. H., Kahlbaum, D. F. Baker, D. G., Wartha, J. H., Keyes, F. A., Boyce D.E., Quinn, F. H. , Assel, R. A., Baker-Blocker, A., and Kurdziel, K. M.: 1980, Summary of Great Lakes Weather and Ice Conditions, Winter 1978-79, NOAA TM ERL ERL GLERL-31, Great Lakes Environmental Research Lab., Ann Arbor, MI.

Environment Canada: 1986, A. 'Great Lakes Climatological Atlas', Saulesleja, A. (ed.), Atmospheric Environment Service, Canadian Government Publishing Center, Ottawa, Cat. NO. EN56-70/1986.

Ferguson, G. A.: 1976, Statistical Analysis in Psychology and Education, 4th edn., Mc Craw-Hill, New York.

Landsberg, H. E.: 1962, 'Biennial Pulses in the Atmosphere', Beitr. Phys. Atmos. 35, 184-194.

Lofgren, B. M., Quinn, F. H., Clites, A. H., Assel, R. A., Eberhart, A., and Luukkonen, C. L.: 2001, 'Climate Change Impacts on Great Lakes Basin Water Resources', J. Great Lakes Res., accepted.

Magnuson, J. J., Robertson, D. M., Benson, B. J., Wynne, R. H., Livingston, D.M., Arai, T., Assel, R. A., Barry, R. G., Card, V., Kuusisto, E., Granin, N.G., Prowse, T. D., Stewart, K. M., 
and Vuglinski, V. S.: 2000, 'Historical Trends in Lake and River Ice Cover in the Northern Hemisphere', Science 289, 1743-1746.

Magnuson, J. J., Webster, K. E., Assel, R. A., Bowser, C. J., Dillin, P. J., Eaton, J. G., Evans, H. E., Fee, E. J., Hall, R. I., Mortsch, L. R., Schindler, D.W., and Quinn, F. H.: 1997, 'Potential Effects of Climate Changes on Aquatic Systems: Laurentian Great Lakes and Precambrian Shield Region', J. of Hydrological Precesses 11, 825-871.

Nicholls, K. H., 1998, 'El Niño, Ice Cover, and Great Lakes Phosphorus: Implications for Climate Warming', Limnol. Oceanogr. 43, 715-719.

Norton, D. C., Assel, R. A., Meyers, D., Hibner, B. A. , Morse, N., Trimble, P. J., Cronk, K., and Rubens, M.: 2000, Great Lakes Ice Cover Data Rescue Project, NOAA TM ERL-GLERL117, Great Lakes Environmental Research Laboratory, Ann Arbor, MI.

Richards, T. L.: 1964, 'The Meteorological Aspects of Ice Cover on the Great Lakes', Mon. Wea. Rev. 92, 297-302.

Rodionov, S. and Assel, R. A.: 2000, 'Atmospheric Teleconnection Patterns and Severity of Winters in the Laurentian Great Lakes Basin', Atmosphere-Ocean, Vol. XXXVIII (4), pp. 601-635.

Rodionov, S., Assel, R. A., and Herche, L. R.: 2001, 'Tree-Structured Modeling of the Relationship between Great Lakes Ice Cover and Atmospheric Circulation Patterns', J Great Lakes Res. 27 (4), 486-502.

Rogers, J. C.: 1976, Long-Range Forecasting of Maximum Ice Extent on the Great Lakes, NOAA Tech. Memo. ERL GLERL-7, 15 pp. [NTIS PB-259 694/8ST].

Sousounis P. J. and Bisanz, J. M.: 2000, Preparing for Climate Change: The Potential Consequences of Climate Variability and Change, United States Environmental Protection Agency, Ann Arbor, MI.

Trenberth, K. E.: 1990, 'Recent Observed Interdecadal Climate Changes in the Northern Hemisphere', Bull. Amer. Meteorol. Soc. 71, 988-993.

Vanderploeg, H. A., Bolsenga, S. J., Fahnenstiel, G. L., Liebig, J. R., and Gardner, W. S.: 1992, 'Plankton Ecology in an Ice-Covered Bay of Lake Michigan: Utilization of a Winter Phytoplankton Bloom by Reproducing Copepods', Hydrobiologia 243-244, 175-183.

(Received 25 September 2001; in revised form 24 May 2002) 